\title{
Notes on some cultic aspects of Italian Prehistory
}

\author{
Renata Grifoni Cremonesi \\ Dipartimento di Scienze Archeologiche, Università di Pisa, Italy \\ grifoni@arch.unipi.it
}

\begin{abstract}
Many cultual manifestations are known in the Neolithic and Metal Ages in Italy. They were associated with pits, dug in the floors of caverns, and stone circles where vases or votive objects were deposited. They related to agricultural rituals, but also to funerary practices associated with birth, life and death. Another type of cults relates to water and water circulation: to cold or warm springs in underground cavities or in surface; to stalactites and their white water; to geothermal phenomena that attracted the interest of people prehistory. Many vases and bronzes were deposited near lakes, sources, rivers and fumaroles.
\end{abstract}

IZVLEČEK - V neolitiku in kovinskih obdobjih poznamo v Italiji mnogo kultov. Povezani so z jamami, vkopanimi $v$ tla $v$ spodmolih in jamskih najdiščih; s kamnitimi okroglimi strukturami, v katere so položene posode in votivni predmeti. Povezujemo jih z religijskimi praksami poljedelcev in rituali ob rojstvu in smrti. Nekateri so povezani z vodo in izviri hladne in tople vode v podzemnih jamah; s stalaktiti in jamskim mlekom; z geotermalnimi fenomeni, ki so privlačili pozornost ljudi v prazgodovini. Mnogo posod in bronastih predmetov je bilo položenih na jezerska obrežja, ob izvire, reke in vulkanske razpoke.

KEY WORDS - Prehistory; cults; rites; Italy

It is not easy to deal with the ideological aspects of prehistory, as this is a subject on which researchers of the highest level have worked from 1880 to the present time. The first problem to face is a misunderstanding that is often created by the definition of a religious happening, which is often confused with witchcraft. It is not always possible to distinguish what lies within the realm of ordinary daily life from what, on the other hand, is an integral part of the ideological world and which has reached us in the form of signs and symbols which, at present, are incomprehensible, or only partially understandable. Moreover, it is also difficult to avoid confusion between religious phenomena, funeral rites and magical happenings while we try to understand, at least in part, some aspects of the ideological world of the past.

The polemics on this subject are extensive and the attempt to elaborate a picture of primitive religion has been the object of several studies and hypothe- ses of classification. Mainly by the second half of the nineteenth century ethnologists were trying - by comparing the religious beliefs of contemporary 'primitives' - to understand those of prehistoric people (Grifoni Cremonesi 2004a.167-177; Grifoni Cremonesi and Martini in press). This problem was also faced in the nineteen hundreds following other models, from the culturalists to the structuralists, with several methodological approaches and with more detailed analysis, at least as regards the domain of cultural anthropology (Lewis 1986; Whitehouse 1992; Wasilewska 1994.62-75). As regards prehistory, the problem still remains undefined, and at this time models of 'Ethno-archaeology' are in use, which unfortunately are often badly applied.

For this reason it is necessary that the interpretation of phenomena that may be defined as cultural should be treated with the utmost prudence, by excluding any suggestion or hypothesis which is often based on generic comparisons with the domains of ethno- 
graphy and of the history of religion, or on non-specific ideas and pre-formed theoretical models. These are often applied with a faulty knowledge of the contexts, of the cultures and of the relevant literature, without taking into due consideration the concrete information to be obtained from the sites themselves (Grifoni Cremonesi 1986.265-269; 1996.78-91; Di Fraia, Grifoni Cremonesi 1996).

Often, indeed, each cave has been given a specific cultic function, based on the simple equation: cave equals sacred site; and a magic-religious meaning has been attributed to every complex or object to which a functional meaning could not be given. In particular, as far as the study of this problem in Italy is concerned, interest in these phenomena was not strong until a short time ago. But Radmilli - following a strong tradition dating from the late nineteen century and the beginning of the twentieth (Rellini 1916.557-622), and continued thereafter by Blanc (1945) - raised again, in the 1960's, the problem of cults, starting from data pertaining to some of the Abruzzi caves. He also pointed out, the first so to do, questions created by the presence of cult pits and circles in the cave deposits (Radmilli 1963; 1975.175-184; Grifoni and Radmilli 1964). The excavations he made and the discovery of several burial sites or monuments, such as the circles of the Pigeon's Cave (Cremonesi 1976; 1985-90.465474), permitted him to hypothesise some modes of funeral rituals and some particular contexts that he tried to relate to the other similar examples. He also tried to find possible relations between cultic patterns and funeral rites in a general picture, from which could emerge an ideology connected with the agricultural world and to the vegetation cycle, death and resurrection. He did this partly by following the guidelines of the historical cultural school, but always keeping in mind the realities of the archaeological data. Unfortunately, his work, like that of many others on the subject, has generally been neglected, perhaps - as I have indicated - because questions of cults never aroused much interest. Only in recent years has it become more popular, perhaps following some recent publications by English authors.

It is often difficult to differentiate the real aspect of a cult from burial rites. This is because the two aspects can often interpenetrate, and also because our knowledge of the effective relations between the various elements of a ritual context are scant. Moreover, if we consider that many excavations lack detailed reports, maps and layouts of burial sites, analysis of living spaces or spaces dedicated to ideologi- cal functions, one may easily understand that interpretation must proceed with the utmost prudence, even if there are multiple and tempting suggestions. If we examine the problem of cults in the Italian peninsula, we can ascertain that, with the coming of the Neolithic, we may see a series of deep changes in the expression of artistic and cultish forms.

The naturalistic art of the Palaeolithic is substituted by schematic and abstract displays that had begun already in the final phases of the Palaeolithic and Mesolithic, and the human figure becomes more important if compared to the Palaeolithic representations of animals. Artistic production declined: the Palaeolithic drawings disappear and there is practically nothing between the western and eastern areas, if we except the hunting scenes of Catal Hüyük, those of the Spanish Levant, and in Italy the Grotta dei Cervi in Porto Badisco. Feminine statuettes predominate, alongside more rare animals or male statuettes. On ceramics, the signs imprinted, scratched, engraved or painted often have a symbolic value (Coppola 1999-2000.67-126; Grifoni Cremonesi $2004 a$. 17-32) that can be related to zoomorphic schematisations, to combinations of triangles, rhombuses, zigzags, spirals, variously interpreted as feminine sexual symbols, water symbols, or of the process of becoming, and from which Maria Gimbutas tried to identify a complex pantheon of divinities (Gimbutas 1974; 1991; Berggren and Harrods 1996.70-73). According to Paolo Graziosi (1973; 1980), the appearance of new iconographic schemes in the Neolithic is a symptom of a sacred value attributed to the implements of daily life. This is within an ample and articulated daily life that extends sacred symbolism to aspects of which the cultic values are not evident today.

The feminine statuettes can generally be related to the Mother Goddess concept, or at least to some forms of feminine deities, and we should note that the production of feminine idols, very abundant in the near east and in the Balkan world is less so in the Italian peninsula, and is practically absent in the western world (Bagolini 1978.41-47; Bagolini and Cremonesi 1992.39-44; Grifoni Cremonesi 2004 . 17-32). The statuettes can be found both in villages and burial sites, and this fact raises the problem of their real meaning within a domestic religiosity, and of a connection with the world of the dead. The complexity of the Neolithic ideological world manifests itself in aspects of rituals which can be referred in a certain way to agriculture and which are often intertwined with funeral rites. They mainly consist of pits 
excavated in cave deposits and which contain pots, offerings of cereals or of fruits, grindstones, or offerings of sacrificed domestic animals (Grifoni Cremonesi 1969.78/91; 1986.256/268; 1996; Grifoni Cremonesi, Di Fraia 1996).

The grindstones are also often found in burials ( $\mathrm{Ba}$ golini, Grifoni Cremonesi 1994.139-170; Grifoni Cremonesi 2006; Grifoni Cremonesi, Radmilli 2000-2001.63-120). It is thus possible to hypothesize a link between life and death which can be identified in the death-resurrection cycle of plants, as we know it, or in other various and complex forms in a great many Mediterranean religions, even if it is not possible to hypothesize a continuity between these and Neolithic cultish forms. The sacred aspect of some places within the elapse of time is quite evident in some caves where burials in pits continue into the metal age and reach the historical age, with the deposition of votive 'stipi' in the same sites (Grifoni, Radmilli 1964; Di Fraia, Grifoni Cremonesi 1996).

Also important are stone circles containing offerings, which are known in several caves of central and southern Italy. They appear to belong to the same concept as the pits, which is to delimit a space that is somehow sacred. The best known are those of the Grotta dei Piccioni in the Abruzzi region belonging to the Ripoli culture, with the remains of infants and valuable artefacts, i.e. painted ceramic vessels, a trumpet made from a charonia shell, the numerous bones of anatids, with small balls of ochre and clay on one end and a clay imitation of one of the pebbles (Cremonesi 1976).

We also have traces of foundation rites, with pits excavated in villages, containing in one instance a zoomorphic vase, and in another, a human skull ( $R a$ di 2004.337-341; Geniola and Mallegni 1975.239249). We also know of inverted vessels (perhaps a way to communicate with the chthonian world) and ritual fragmentation. There are also - in the final Neolithic with the Serra d'Alto culture (Lo Porto 1989) - two evident altars of stones in two caves, the Cala Scizzo and Grotta Pacelli near Bari (Striccoli 1998; Geniola and Tunzi 1980.125-140), and the great cultic hypogeum Manfredi, the first example of Neolithic hypogeism, with skulls of deer and roebuck, and painted pottery placed along the sides (Geniola 1979.52-93; 1987.771-781). These three sites can be considered real shrines. The Grotta dei Cervi of Porto Badisco must have been another important shrine, the only known example of parietal art of this period; its graphemes have been interpreted by Graziosi (1980) as extreme stylisations of the human form.

From this we reach the abstract symbols which are identical to those found on the painted ceramics of Masseria La Quercia and of Serra d'Alto. The funeral rites, which are extremely simple in the ancient Neolithic - with the deceased buried in simple holes with rare examples of offerings (grindstones and cereals) - become more complex with the painted ceramics and with the square mouthed vase culture. Ceramic vessels, ornaments and valuable objects appear, the graves are sometimes encircled by stones, and next to the villages, spaces are dedicated to the dead, thus creating a real necropolis (Grifoni Cremonesi 2001; 2004b.17-32; 2006). The first hypogea and megalithic cysts appear at the end of the Neolithic, and are a prelude to the great phenomenon of the hypogeism that will develop at the end of the third millennium.

In the Neolithic period, cults dedicated to water are also known. Water has always been considered a fundamental element of life, and from the Palaeolithic we can see traces of the veneration of water in its various aspects (liquid, solid as concretions, gaseous) (Whitehouse 1992). But it is with the Neolithic that water becomes even more important to people beginning to practise agriculture, for whom water was a force of nature with vivifying and sometimes medicinal properties (Grifoni Cremonesi 1996; Bernabei and Grifoni Cremonesi 1995-1996.331-366).

Cultish forms in this period are known from labyrinthine caves, with depositions of vessels near small lakes or subterranean springs, often connected with particular concretions or notable dripping sources. The Italian caves with Neolithic complexes that can be connected to water cults are Grotta Scaloria Bassa (Manfredonia), Pozzi della Piana (Orvieto), Grotta dei Meri (Monte Soratte), Grotta Zinzulusa (Castro Marina) and, probably, the Grotta Verde of Alghero.

The Scaloria Bassa is a lower hall pertaining to the Grotta Scaloria of Manfredonia, discovered in 1967: it is a large hall rich in concretions, at the bottom of which there is a small lake. The Neolithic people that utilized this area left ceramic vessels around the stalactites or on the top of intentionally broken stalactites. In a recess near the pool, a human skull and other bones were deposited, and there was a fireplace nearby, with the remains of partly burned animal bones. The vessels, about sixty, belong to the 
cultic context of the ceramics painted with red bands that was prevalent in southern Italy in the first half of the fourth millennium BC. They are all interpreted as figuline ceramics of a particular value, painted with red bands and brown margins inserted with a particular 'negatively applied' technique. It looks certain, for this particular cave, that the cult consisted exclusively of collecting the water which was dripping and was difficult to take outside, as most of the vessels have open mouths. The fact of intentionally breaking the stalactites in order to place the pots may tempt one to hypothesize some sort of veneration in this phenomenon. Obviously, it is impossible to say whether the water was collected for religious, magical or therapeutic uses. The Neolithic people also carved a small basin in the rock and did not place vessels contiguous to the nearby lake, so that the cult was directed to the dripping sources and not to the 'normal' water. Pertaining to the same period of the Scaloria Bassa, but belonging to the Tuscan and Latium period of engraved lines ceramics, are the depositions of ceramic vessels in the Grotta dei Meri at the Monte Soratte and in the Pozzi of the Orvieto plain. In both cases the caves consist of large complexes of labyrinthine galleries difficult of access. In the Grotta dei Meri (Segre 195152.136-139) a jar was placed under a source of dripping water at the end of a long gallery. It is reached from one of the access wells and placed at the crossroads of several underground passages. Also, in this case it is a clear example of the collection of particular waters secretly, which appears to exclude a supply of a functional kind.

At the Pozzi Della Piana there is a more complicated context (Passeri 1970.225-251). Lithic and ceramic material has been found on the floors of various galleries and halls that are developed on three levels or in natural recesses on the sides. In particular, some cups, 5 to 7 centimetres high, were placed upturned in cracks of the rocks around a large pool surrounded by stalagmites and stalactites. Flask-shaped vessels were placed within other small pools of water, partly protected by concretions. A circular pit, 40 centimetres wide and 50 deep, dug in the rocky floor, was filled with ochre clods and grindstones. The grindstones in caves were often associated with burials or placed in pits.

In the final Neolithic in Apulia, at about the end of the fourth or beginning of the third millennium BC we have another deposit of vessels around a water pool in the Grotta Zinzulusa of Castro Marina (Lecce): eleven vessels, consisting of assorted bowls and flask-shaped pots, were placed along the banks of a small lake situated at the end of a cave labyrinthine and rich in concretions, and which is reached after a sharp descent (Zezza 1984.69-81).

The case of the Grotta Verde of Alghero is peculiar: the cave opens at $75 \mathrm{~m}$ above sea level and develops into a hall that reaches a small lake of brackish water which is at sea level. By means of a well six metres deep, one can reach another hall rich in stalagmite concretions, and in which there were human remains. Again, from this place one reaches, through a narrow tunnel, a large hall situated at minus ten metres and full of underlying sea water which has an upper layer of fresh water about two to six meters deep. There have been several finds here of impressa ceramic belonging to the upper Neolithic which can be dated to the fourth millennium BC, which were placed either in the tunnel or in the undersea cavity. They are mostly flasks, perhaps used to draw water (Tanda 1978.45-94), but it is difficult to determine if the vessels were connected with rituals performed in the cave, or if they were simply used to collect fresh water. The latter hypothesis is less convincing given the difficulty of reaching the pool.

In all these instances we have deposits of vessels, often of a peculiar shape, placed near water surfaces or under dripping water sources, in labyrinthine caves of difficult access. It appears that we are dealing with a particular phenomenon that excludes the collecting of water for everyday use by the fact of the peculiarity of the sites and the type of deposits, and that these phenomena appear to belong more to the domain of ritual. The cults appear to be addressed more to the underground waters, so that we may infer a particular importance of these kinds of waters, perhaps considered sacred, therapeutic or magical. On the other hand, up to the present day the collecting of milky water from the caves has continued in caves dedicated to St Michael, or in the 'Lattaie' (Milky) caves, which women unable to lactate used to visit (Di Fraia, Grifoni Cremonesi 1996).

It appears that there are no other connections with other forms of Neolithic ritual, such as offerings of vegetables or of peculiar objects, human remains, excluding the pit in the Pozzi della Piana. The phenomenon of collecting drip waters is proved again in Italy at the end of the Copper Age (end of the third to the beginning of the second millennium $\mathrm{BC}$ ) at the Buca del Rospo on Mt Cetona, near Chiusi. In this instance also, two vessels were found partly in- 
serted into the stalagmite in areas of intense dripping, having being taken through a deep well that makes access to the final part of the cave very difficult (Zanini 1988.184-190). Notwithstanding the scarcity of documents, it is still possible to guess at some common forms and symbols which recur throughout the Neolithic, even if with local variants.

The votive pits, the stone circles, the feminine and zoomorphic statuettes - which connect us to the Balkans - the offerings of cereal grains and of grindstones, the hypogeic water cults, the sacredness of some sites - confirmed by the continuity of the cults up to the historical era - allow us to hypothesize the existence of a religious ideology based on the importance of agriculture and on the dominance of the feminine element, a fact which we may perceive from some decorations on ceramics. I do not believe that it is possible to accept the attribution of the various Neolithic symbols to the divinities of later pantheons, as Ms. Gimbutas has. We may only distinguish the various exterior forms of cults that remain unknown to us in their essence and only set forth hypotheses. We cannot conceal a certain envy for the certainty with which some authors - whose knowledge of the Italian Neolithic is by the way quite limited - are able to reconstruct with assured exactness, ideologies, social systems, religions and rituals (Brown 1997.184-194; Skeates 1991; 1995.122134; 1997.79-86).

Surely it is not easy to disentangle oneself from the complexities of the Italian Neolithic and even less in the intricate framework of the burial aspects and of the cultic phenomena (Grifoni Cremonesi 2003. 259-274). But, prior to beginning to elaborate theories and to manifest certainties on the social and ideological aspects of Neolithic people, we must carefully analyze the data at our disposal, which are too few - in our opinion - to allow us to do more than express some generalities. Without doubt we may relate the various form of funeral rituals and cults during the Neolithic period to some of the changes that we observe regarding economic typologies, with an increase of wealth and exchange, and we may also have a glimpse of some changes in ideologies, mainly between the middle and late Neolithic. But this is not enough to affirm with certainty the existence of definite powers - masculine or feminine social hierarchies in a sort of mixture of examples borrowed from recent cultures, thereby misunderstanding the inputs that may be provided by ethnoarchaeology.
But it is difficult, also in the event of there being plentiful information, to interpret correctly everything related to the funerary and ideological domain. It is very difficult, if not impossible, to attempt to reconstruct full sequences of phenomena if these are isolated from their own context and reduced to single entities of particular objects, or bare skeletons, or heaps of bones. During the Copper Age further and more important changes appear on the ideological level, apart from the technological one. The more common symbols appear now to refer to a world in which the dominant element assumes masculine connotations: it consists of daggers, axes, halberds, necklaces, and cloaks, symbols which we find on stele statues and on the rock engravings of the Alps, and which are very widely diffused (Casini 1994; Casini et al. 1995). The comparison of these symbols with objects that were placed in masculine tombs is evident, and the simultaneous appearance of solar symbols has induced many researchers to hypothesize the existence of uranic cults. Those cults are typical, according to some, of masculine groups with a warrior dominance, even if feminine stele statues are present and also testimonials of the perseverance of agrarian rituals in some caves. With the testimonials of particular cults we should remember the pit with the remains of a horse covered with two puppies in Maccarese village near Rome (Manfredini 2002) and the burial of a bovid in an Eneolithic site near Florence, where a tumulus has been found within the inhabited area (Sarti and Martini 1993). It seems that small statuettes disappear and, apart from the splendid engravings at Monte Bego and Valcamonica, in the remaining part of the peninsula we have only scant evidence which may be dated with difficulty - of schematic rock engravings in some caves and shelters. Also in decline are decorations found on ceramics, but particular motifs in 'stralucido' appear on some vessels of the Rinaldone culture, also with solar symbols.

During the Copper age, in the third millennium BC, the evidence for water cults is rarer, but often some rock engravings appear to be related to springs, sources or waterfalls (De Lumley 1995). On the other hand, the exploitation of therapeutic waters now begins, as is indicated by the Panighina Spring at Bertinoro, where a well has been dug and in which several vessels were found, probably offerings to the medicinal source (Morico 1996.153-162).

With the Bronze Age the explicit evidence is increasingly rare and there is no major artistic evidence, but we may note solar symbols (discs, crosses) on 
ceramics, to which are added the shapes of water birds, which symbolize the sun vessel (Damiani 1992.81-94). There are also equine statuettes, which are also connected to solar cults (Bettelli 1997.720741). Agrarian cults are well evidenced, with offers of cereals and leguminous plants in the caves, which in some way continue the Neolithic cults, and instead, water cults are more common (Bernabei and Grifoni Cremonesi 1995-96.331-366; Pacciarelli 1997). During the Bronze Age and up to the Roman period, vessels were placed in the farthest halls of the Grotta dell'Orso at Sarteano (Grifoni 1967.53115; Cremonesi 1968) and in the Grotta Tomba dei Polacchi near Bergamo (Poggiani Keller 1979). Again regarding the connection of people with waters, in the Middle Bronze age we have several examples of caves with vessels placed along inner creeks or near sources. The vessels are often associated with the remains of cereals, seeds and fruits, which are placed either in the vessels or on the ground. Sometimes they are associated with the human skeleton remains (Guidi 1980.148-155; 1986.239-247; 1989-90. 403-414; 1991-92.427-437).

Among the better known and more evident examples are Grotta Nuova and Grotta Misa in Latium. In the first the vessels were placed in the brook that flows through the cave. Some of them contain wheat and broad-beans, others are placed in invert position (Cocchi Genick, Poggiani Keller 1984.31-65). In Grotta Misa, which is also crossed by a streamlet, and which contained several vessels and a fireplace whose ashes had been widened into a circular shape in order to place - at the centre of the ash circle small, precisely separated mounds of wheat, millet and broad-beans (Negroni Catacchio et al. 1989-90. 579-597). At the Val di Varri Cave in the Abruzzi there is a small lake and, during rainy periods, there is a torrential flow; it is very abundant in concretions, one of which has a peculiar anthropomorphic shape. Apart from several vessels, seven fireplaces have been found there which contained, as in the Grotta Misa, the remains of wheat and broad-beans (Güller and Segre 1948.269-281). The small Cave of the Water or of the Stipe near Corchiano (Latium) contains a source which was an object of veneration up to Roman times: the oldest findings are from the Middle Bronze age (Rellini 1920.6-174).

The cave giving the most important information is the Grotta Pertosa near Salerno. A river runs through it, filling the terminal part of the cave. Two pile-dwellings were built in the Middle Bronze Age, and apart from a great number of the pots, a deposit of 324 miniature vessels has been found in the farthest part of the cave, lined and piled up in a cavity in the wall. The assemblage is interpreted as a votive offering (Carucci 1907; Trucco 1991).

In Grotta del Mezzogiorno in the Sentino gorge (Marche), dripping water spring was associated with several 'Apennine' decorated ceramic vessels, and with the fireplace and small holes containing wheat and wee wiled broad beans. Similar scenario was hypothesised in Grotta dei Baffoni, Grotta del Prete and Grotta di Frasassi (Pacciarelli 1997).

A notable increase in votive offerings related to hypogeal waters is recognized in in the Middle Bronze Age. It differs from the Neolithic practices, related to agrarian rituals, and funeral rites we mentioned before. It is worth notice the interest moves to running waters or sources and away from underground pools, and the offerings are deposited more frequent in caves which are not labyrinthine and more easily accessible. There are also cases of dedications to surface waters such as at the Laghetto del Monsignore near Campoverde (Latium), where ceramic vessels were placed from the Middle Bronze Age until the sixth century BC, near spring pools (Crescenzi 1978.51-55; Guidi 1980.148-155).

All these data are from the Centre and Southern Italy: instead, during the Bronze Age, in the northern regions, different types of water rite appear, which consist in offerings of bronze objects, mainly swords, in rivers, streams and lakes, from the middle Bronze Age till the Final Bronze Age.

Other kinds of phenomenon was linked with the more evident appearances of secondary volcanism, particularly sulphur springs, fumaroles, hot steam sources, thermal sources. Even if the research is still scant, it shows an interest which may be linked to some forms of rituals connected to the chthonian divinities, perhaps originating from the strangeness and the might of the volcanic phenomena. The Grotta dello Sventatoio in the Latium region is a cave with four halls connected by narrow passages reaching a depth of minus 30 metres. It is classified as a thermal cave (Guidi 1991-92.427-437) and - especially in winter - air currents and steam issue from it. Pottery fragments, deposited there, belong to about 400 vessels from Early and Middle Bronze age. They were associated with food morsels (including a cereal pancake) and containing seeds of wheat, barley and broad-beans. The remains of the skulls of three infants with traces of exposure to fire, and bones of 
pig, sheep and ox were deposited in the cave as well. The steam from the cave may have influenced the choice of the cave itself for the votive offerings.

Also connected to a cult of the chthonian world, we may relate the Bronze Age pits of the Capo Graziano culture of the Caldara of Panarea (Eolian Islands) in an area impossible to inhabit and where there is still volcanic activity. It is indeed an area near to the beach, with abundant fumaroles that also boil in the sea; the soil is so hot so that it is impossible to walk on it. Notwithstanding, it was used in the final Neolithic and in the Bronze Age: people dug small pits lined with pebbles cemented with sulphurous mud. The site was frequented also in the Hellenistic and Roman age and it is difficult to see it as a dwelling (Bernabò Brea and Cavalier 1968). To similar phenomena one may associate also the ceramic vessels deposited from the Early to the Late Bronze Age on the banks of the Pool of the Colonnelle at Guidonia near Tivoli (Rome): it is a sulphurous lake and the atmosphere of the place is very troubled by the vapours and by the noxious smell, but notwithstanding this, offerings were continuously made through the ages (Guidi 1986.239-247). On the other hand, the caves at Latronico (Potenza) are difficult to interpret. They are some distance from the hot sulphurous sources (the site is called, in effect, Calda, and there are thermal spas), which were frequented from the Mesolithic to the Bronze Age, and which Rellini (1910) interpreted as a site dedicated to a cult of the 'healing waters' during the Bronze Age.

More recent digs, however, show that the caves were mainly utilized as dwellings (Cremonesi 1978.5155; Bianco 1984). Unfortunately, the older excavations did not take into account stratigraphy and the exact position of finds, so that the real connection between the sulphurous waters and the vessels full of cereals and of fruits that were found at the time is still an open problem. Offerings of vessels, arms, and jewels are confirmed also in other areas of se- condary volcanic activity near fumaroles active along the dorsal of the Apennines (Grifoni Cremonesi 1999.114-135; 2005.10-26). Also important is the phenomenon of the deposition of swords, and also of jewels, in lakes and rivers.

The ideology appears to become more and more complex within societies that underwent - during the Bronze Age - noteworthy and important changes due to the continuous development of new technologies, of a well-developed agriculture also enriched by the new cultures of oil and wine, and to contacts with more developed societies, such as the Mycenae (Peroni 1989; 1996). These new aspects of the social structure obviously brought innovations in the ideological world, innovations which will take codified forms in the Iron Age and become institutionalized religions in the historical age. In any case, in these religions some archaic element will resist in the new context, even if in latent and secondary aspects of the new rites. They consist of agrarian cults, at which point we may remember the mundus of the Romans, the gardens of Adonis, the rite of the foundation furrow, but also cults dedicated to waters which continue up to the present - with the dedication of caves, rivers, springs, first to the divinities of the Greek and Roman worlds and, after that, with Christianity, to saints or to the Virgin Mary. This is why we are far from able to give a definite solution to the problem: the domain of religious phenomena in prehistory can supply only hypotheses or brief fragments of intuition, which can be accepted only on the underlying condition that there is a correct analysis of the data and of the contexts. As regards the interpretation of all the phenomena that we could identify, the possibilities that are offered us are up to now too numerous and influenced by our way of thinking, and too tentative to connect our way of thinking to that of prehistoric peoples or, to cite De Martino, to think the present time unduly rendered antique.

\section{REFERENCES}

BAGOLINI B. 1978. Le immagini femminili nell'arte neolitica dell'Italia settentrionale. In A. Aspes (ed.), L'arte preistorica nell'Italia settentrionale. Verona: 41-47.

BAGOLINI B., CREMONESI G. 1992. Manifestazioni artistiche del neolitico italiano Atti Riunione Scientifica Istituto Italiano Preistoria e Protostoria XXVIII: 39-44.
BAGOLINI B., GRIFONI CREMONESI R. 1994. Il neolitico italiano. Facies culturali e manifestazioni funerarie. Bullettino di Paletnologia Italiana 85: 139-170.

BERGGREN K., HARROD J. B. 1996. Understanding Marija Gimbutas. Journal of Prehistoric Religion X: 70-73. 
BERNABEI M., GRIFONI CREMONESI R. 1995-96. I culti delle acque nella preistoria italiana. Rivista di Scienze Preistoriche 47: 331-366.

BERNABO' BREA L., CAVALIER M. 1968. Meligunis Lipàra, III. Flaccovio, Palermo.

BETTELLI M. 1997. Elementi di culto nelle terramare. In Bernabo' Brea M., Cardarelli A., Cremaschi M. (eds.), Le Terramare. La più antica civiltà padana. Milano: $720-$ 741.

BIANCO S. (ed.) 1984. Testimonianze Archeologiche nel territorio di Latronico. Galatina.

BLANC A. C. 1945. Il sacro presso i primitivi. Roma.

BROWN K. 1997. Social control or "Opium of the people?". The role of religion in the neolithic of the Tavoliere. In C. Bonsall and C. Tolan-Smith (eds.), The Human Use of Caves. BAR International Series No. 667 Oxford: 184-194.

CARUCCI P. 1907. La grotta preistorica di Pertosa (Salerno). Napoli.

CASINI S. (ed.) 1994. Le pietre degli Dei. Bergamo.

CASINI S., DE MARINIS R. C., PEDROTTI A. 1995. (eds.) Statue stele e massi incisi nell'Europa dell'età del rame. Notizie Archeologiche Bergomensi 3.

COCCHI GENICK D., POGGIANI KELLER R. 1984 La collezione di Grotta Misa conservata al Museo Fiorentino di Preistoria. Studi di Antichità in onore di G. Maetzke I: 31-65.

COPPOLA D. 1999-2000. Grotta Sant'Angelo (Ostuni, Brindisi), Scavi 1984: dalla ceramica graffita al linguaggio simbolico. Atti Società Preistoria e Protostoria FriuliVenezia Giulia XII: 67-126.

CREMONESI G. 1968. La Grotta dell'Orso di Sarteano. I livelli dell'età dei metalli. Origini II: 247-331.

1976. La Grotta dei Piccioni di Bolognano nel quadro delle culture dal neolitico all'età del bronzo in Abruzzo. Pisa.

1985-1990. Su alcune manifestazioni di culto del neolitico abruzzese. Abruzzo XXIII-XXVIII: 465-474.

CRESCENZI L. 1978. Campoverde. Archeologia Laziale 1: $51-55$.

DAMIANI I. 1992. Elementi figurativi nell'artigianato della tarda età del Bronzo. Atti Riunione Scientifica Istituto Italiano Preistoria e Protostoria XXVIII: 81-94.
DE LUMLEY H. (ed.) 1995. Le grandiose et le sacré. Gravures rupestres protohistoriques et historiques de la région du Mont Bego. Aix-en-Provence.

DI FRAIA T., GRIFONI CREMONESI R. 1996. La Grotta $S$. Angelo sulla Montagna dei Fiori. Testimonianze dal neolitico all'età del bronzo e il problema delle frequentazioni cultuali nella preistoria. Istituti Editoriali e Poligrafici Internazionali. Pisa - Roma.

ELIADE M. 1961. Images and Symbols, Studies in Religious Symbolism. Harvill Press. London.

GENIOLA A. 1979. Il Neolitico della Puglia settentrionale e centrale. In La Puglia dal paleolitico al Tardoromano: 52-93.

1987. La cultura di Serra d'Alto nella Puglia centrale. Atti Riunione Scientifica Istituto Italiano Preistoria e Protostoria XXVI: 771-781.

GENIOLA A., MALLEGNI F. 1975. Il calvario neolitico di Lanciano (Chieti), note paletnologiche e studio antropologico. Atti Società Toscana Scienze Naturali, Memorie, ser. A, LXXXII: 237-253.

GENIOLA A., TUNZI A. M. 1980. Espressioni cultuali e d'arte nella Grotta di Cala Scizzo presso Torre a Mare (Bari). Rivista di Scienze Preistoriche XXXV: 125-146.

GIMBUTAS M. 1974. Gods and Goddesses of Old Europe. University California Press. Berkeley and Los Angeles.

1991. Il Linguaggio della Dea. Officine Grafiche Fratelli Stianti. Sancasciano.

GRAZIOSI P. 1973. L'arte preistorica in Italia. Firenze.

1980. Le pitture preistoriche della Grotta di Porto Badisco. Origines. Firenze.

GRIFONI R. 1967. La Grotta dell'Orso di Sarteano. Il Neolitico. Origini I: 53-115.

GRIFONI CREMONESI R. 1969. La Grotta cultuale delle Marmitte presso Ofena (L'Aquila). Atti Società Toscana Scienze Naturali, Memorie, ser. A 77: 78-91.

1986. Alcuni dati relativi a fenomeni funerari con implicazioni cultuali nella preistoria e problemi di interpretazione. Dialoghi di Archeologia 2: 265-269.

1996. Le grotte e la loro funzione. Premessa metodologica, "L'Antica età del bronzo". Atti del Convegno di Viareggio 1995: 305-311.

1999. Relationships between Man, Hypogeic and Thermal Waters in Italian Prehistory. In R. Cataldi, S. Hodgson, J. W. Lund (eds.), Stories from a Heated Earth. 
Our Geothermal Heritage, Geothermal Resources Council and International Geothermal Association, Sacramento: 114-135.

2000. Alcune osservazioni sui culti delle acque e sulla frequentazione delle grotte dal neolitico all'età del rame. Atti del Convegno Grotte, Acque, Dei, Imola 1997, OCNUS 7: 159-165.

2000. Sull'interpretazione di alcuni aspetti funerari e cultuali nel neolitico abruzzese. In P. Biagi (ed.), Studi sul Paleolitico, Mesolitico e Neolitico del bacino adriatico in ricordo di A. M. Radmilli. Quaderni Società Preistoria Protostoria Friuli Venezia Giulia 8: 127-139.

2001. La frequentazione delle grotte nella preistoria: tracce e simboli. BORA 2000, Incontro Internazionale di Speleologia, Trieste 2000. Trieste: 175-179.

2003. Sepolture neolitiche dell'Italia centro meridionale e loro relazioni con gli abitati. Atti Riunione Scientifica Istituto Italiano Preistoria e Protostoria XXXVIXXVI: 259-274.

2004a. Aspetti del mondo ideologico nella preistoria. In E. Ingravallo (ed.), Il fare e il suo senso. Congedo Editore. Lecce: 167-177.

2004b. Motivi decorativi e simboli nel neolitico italiano. Atti del Incontro di Studi Preistoria e Protostoria in Etruria VI: 17-32.

2005. Il rapporto dell'uomo con le manifestazioni geotermiche in Italia dalla Preistoria fino all'Alto Medioevo. In M. Ciardi and R. Cataldi (eds.), Il calore della terra. Contributo alla storia della Geotermia in Italia. Pisa: 10-26.

2006. Sepolture e rituali funerari nel Neolitico in Italia. In F. Martini (ed.), La cultura del morire nelle società preistoriche e protostoriche italiane, Origines. Firenze: 87-107.

2006. in press. Témoignages de cultes et de rites au Néolithique et à l'age des métaux en Italie, Atti Convegno Internazionale "A l'origine de la pensée symbolique méditerranéenne», Tenda.

GRIFONI CREMONESI R., MARTINI F. in press. La frequentazione rituale delle grotte nel Paleolitico. Atti Convegno "Toirano e la Grotta della Basura", Bordighera.

GRIFONI R., RADMILLI A. M. 1964. La Grotta Maritza e il Fucino prima dell'età romana. Rivista di Scienze Preistoriche 19: 53-27.

GRIFONI CREMONESI R., RADMILLI A. M. 2000-2001. La Grotta Patrizi al Sasso di Furbara. Bulletino de Paleontologia Italiana 91-92: 63-120.
GUIDI A. 1980. Luoghi di culto dell'età del Bronzo Finale e della Prima Età del Ferro nel Lazio meridionale. Archeologia Laziale 3: 148-155.

1986. Gli insediamenti perilacustri di riva d'età protostorica nel Lazio centro meridionale. Quaderni $d i$ Protostoria 1: 239-247.

1989-90. Alcune osservazioni sulla problematica delle offerte nella protostoria dell'Italia centrale. Scienze dell'Antichità 3-4: 403-414.

1991-92. Recenti ritrovamenti nel Lazio: un riesame critico del problema dell'utilizzazione delle cavità naturali, Atti del Convegno L'età del Bronzo in Italia nei secoli dal XVI a.C. al XIV a.C. Rassegna di Archeologia 10: 427-437.

GÜLLER A., SEGRE A. G. 1948. La stazione enea del Grottone di Val de'Varri nell'Appennino abruzzese. Rivista di Antropologia XXXVI: 269-281.

GUILAINE J. (ed.) 1998. Atlas du néolithique Européen, Vol. $2 A$.

LEROI GOURHAN A. 1964. Les religions de la préhistoire. Presses Universitaires de France. Paris.

LEWIS I. M. 1986. Religion in context. Cult and Charisma. Cambridge University Press. Cambridge.

LO PORTO F. G. 1989. L'insediamento neolitico di Serra d'Alto nel Materano, Monumenti Antichi dei Lincei. Serie monografica LIII. L'Erma di Bretschneider.

MANFREDINI A. 2002. Le dune, il lago, il mare. Una comunità di villaggio dell'età del Rame a Maccarese. Origines. Firenze.

MORICO G. 1996. Panighina di Bertinoro (Forlì), Quando Forli non c'era, Forli: 153-162.

NEGRONI CATACCHIO N., DOMANICO L., MIARI M. 198990. Offerte votive in grotta e in abitato nelle valli del Fiora e dell'Albegna nel corso dell'Età del Bronzo: indizi e proposte interpretative. Scienze dell'Antichità 3-4: 579597.

OTTE M. 1995. Prehistory of Religion: Data and Methods. Journal of Prehistoric Religion IX: 55-69.

PACCIARELLI M. (ed.) 1997. Acque, Grotte. Dei. 3000 anni di culti preromani in Romagna, Marche. Abruzzo, Imola.

PASSERI L. 1970 Ritrovamenti preistorici nei Pozzi della Piana (Umbria). Rivista di Scienze Preistoriche 25: 225251. 
PERONI R. 1989. L'età del bronzo nella penisola italiana. Popoli e Civiltà dell'Italia antica. Biblioteca di Storia Patria, Vol. 9. Tipografia Mancini, Guidonia. Roma.

1996. L'Italia alle soglie della storia. Laterza editore. Bari.

POGGIANI KELLER R. 1979. Culto delle acque nella grotta Tomba dei Polacchi. Annali Benacensi 5: 173-182.

RADI G. 2004. Deposizione cultuale nell'abitato del neolitico antico di Colle Santo Stefano (Abruzzo). Archeologia Pisana, Scritti per Orlanda Pancrazzi. Pisa: 337- 341.

RADMILLI A. M. 1962. Documentazione sulla tradizione orale nella preistoria. La veneranda Anticaglia X(3): 816.

1975. Culti di fertilità della terra testimoniati in alcuni giacimenti neolitici italiani. Atti Colloquio Internazionale Les religions de la Préhistoire "Valcamonica Symposium" Capodiponte 1973. Capodiponte: 175184.

RELLINI U. 1916. La caverna di Latronico e il culto delle acque salutari nell'età del Bronzo. Monumenti Antichi dei Lincei XXIV: 557-622.

1920. Cavernette e ripari preistorici nell'Agro Falisco. Monumenti Antichi dei Lincei XXVI: 6-174.

SARTI L., MARTINI F. 1993. Costruire la memoria. Archeologia preistorica a Sesto Fiorentino (1982-1992). Garlatti e Razzai. Firenze.

SEGRE A. G. 1951-52. Orcio rinvenuto al Monte Soratte presso Roma. Bullettino di Paletnologia Italiana 8: 136139.

SKEATES R. 1991. Caves, Cult and Children in Neolithic Abruzzo, Central Italy. In P. Garwood, P. Jennings, R. Skeates and J. Toms (eds.), Sacred and Profane, Commit- tee for Archaeology, Monograph No. 32. Oxbow, Oxford: $122-134$.

1995. Transformations in mortuary practice and meaning in the Neolithic and Copper Age of Lowland EastCentral Italy. In W. H. Waldren, J. A. Ensenyat and R. C. Kennard (eds.), Ritual, Rites and Religion, IIIrd DEYA International Conference of Prehistory. Vol. I, BAR International Series No. 611, Oxford: 212-238.

1997. The Human Uses of Caves in East-Central Italy during the Mesolithic, Neolithic and Copper Age. In C. Bonsall and C. Tolan-Smith (eds.), The Human Use of Caves. BAR International Series No. 667, 0xford: 79-86.

STRICCOLI R. 1988. Le culture preistoriche di Grotta Pacelli (Castellana Grotte, Bari). Schena Editore. Fasano.

TANDA G. 1978. Il Neolitico Antico e Medio della Grotta Verde, Alghero. Atti della Riunione Scientifica Istituto Italiano Preistoria e Protostoria XXII: 45-94.

TRUCCO F. 1991-92. Revisione dei materiali di Grotta Pertosa. L'età del Bronzo in Italia nei secoli dal XVI a. C. al XIV a.C., Rassegna di Archeologia: 471-479.

WASILEWSKA E. 1994. The Search of Impossible: The Archaeology of Religion of Prehistoric Societies as an Anthropological Discipline. Journal of Prehistoric Religion VIII: $62-75$.

WHITEHOUSE R. 1992. Underground Religion. Cult and cultures in Prehistoric Italy. Accordia Research Center. London.

ZANINI A. 1988. La Buca del Rospo. Testimonianze della prima età dei Metalli. Archeologia in Valdichiana. Multigrafica Editrice. Roma: 184-190.

ZEZZA M. G. 1984. Vasi Eneolitici della Grotta Zinzulusa di Castro (Lecce), Scientifiche del Museo Comunale di Paleontologia. I Quaderni 2: 69-81. 